\title{
THE IMPACTS OF ACADEMIC SERVICES AND CAMPUS ATMOSPHERE TO STUDENTS' SATISFACTION AND RETENTION
}

\author{
Yohan \\ yohan.nur.yahya@gmail.com \\ IAIN SAS Bangka Belitung
}

\begin{abstract}
Pelayanan akademik dan suasana kampus merupakan dua hal yang seringkali dapat menganggu kenyamanan dan kepuasan mahasiswa dalam proses penyelesaian kuliah. Melalui kajian yang dilakukan didapati bahwa dampak dari pelayanan kampus yang kurang prima dan suasana kampus yang kurang mendukung menyebabkan banyak mahasiswa yang merasa tidak nyaman berada di kampus dan tidak betah berlama-lama berada di dalam kelas. Disamping itu, terdapat beberapa dosen yang gagal memenuhi jumlah minimal kehadiran kelas. Sedangkan aktifitas konsultasi akademik yang dapat dimanfaatkan sebagai wadah dalam menyampaikan pesanpesan akademik bagi keberhasilan mahasiswa belum sepenuhnya dimaksimalkan oleh sejumlah dosen dan juga mahasiswa yang bersangkutan. Akibatnya muncul 'mis-komunikasi,' sehingga banyak mahasiswa yang gagal meraih kepuasan dan kenyamanan akademik. Padahal kepuasan akademik dan kenyamanan dalam proses perkuliahan merupakan pendorong kesuksesan akademik mereka guna menghindari kegagalan penyelesaian kuliah. Oleh sebab itu diharapkan agar pihak yang berkompeten di kampus dapat meningkatkan pelayanan yang lebih prima dan mendorong para dosen, mahasiswa dan seluruh civitas akademikanya untuk terlibat secara aktif dalam membangun sekolah tinggi ini bagi kemajuan masa depan kampus agar dapat meminimalisir mahasiswa yang 'drop out' dengan menutup segala kekurangan yang ada.
\end{abstract}

Keywords: Academic Service, Campus Atmosphere, Impacts, and Students' Satisfaction and Retention 


\section{INTRODUCTION}

In academic setting, the urgent of study of students' satisfaction assists higer education make their policy more responsive to the requirements of a current demanding trend. Besides, it would determine the future's demeanor of colleges potential policy in achieving their educational institution targets and making satisfaction educational products. Thus, in attaining their goals, making more responsive policy to the changing requirements of higher education trends and succeeding satisfaction to the educational products, students' contentment to their campus should be primarily fixed on.

One of the most important satisfaction products of educational institutions could be determined from both qualified graduates and students' academic retention. The qualified graduates can be a appraising rod of colleges in manifesting their goals. Additionally, to make students be constantly involved in academic retention for each semester can be a short-term goal of colleges mission.

Producing satisfaction product of educational institutions and in sustaining students' academic retention is a hard thing to perform because all academic members of colleges must work well with their main duties. Besides, students must also understand the value of their education and be satisfied with their overall experience in order to promote and support their higher educational institution as a student or as an alumnus. As stated by Bryant (2006) and Ozgungor (2010) in Tessema et al, (2012) that "satisfaction is a relevant measure because many studies have demonstrated that other factors being equal, satisfied individuals are likely to be willing to exert more effort than unsatisfied individuals." In this case, the satisfied students were seemingly to exert more effort in their educational studies by taking actions such as regularly caring for their classes and befalling more involved in their coursework and institution. Thus, the importance of academic satisfaction for them is to ensure whether colleges are gratifying their missions and goals.

Students' academic satisfaction could not be effortlessly obtained without preparing and applying an entire academic service quality and comfortable campus atmosphere. To achieve these, there should be definitely an indistinguishable understanding among all college members. Many students did not attain their self-complaceny in academic setting because of some effects. In this study, academic service quality and campus atmosphere could be of two interrelated possible effects that frequently prevented them from delighting their academic satisfaction. Therefore, their academic satisfaction level was the major concern to college and university academic members and educational planners.

The two interrelated possible effects, as mentioned above, could be indicated from the conditions where many students often felt weary and anxiety when attending class and setting their campus up whether for academic purposes in general or for administration accomplishment in particular. For some cases, a number of lecturers could not fulfill their obligation in mentoring their students for a minimum class attendance. Besides, some administration staffs frequently showed an uncomfortable manner when giving administration services. In fact, many students could gain the dissatisfied services as an individual wherein they need the solution of their financial problems, complains for their unsatisfied administrative assistances and guidance for academic success. Additionally, in several students' individual case, they felt uncomfortable to be totally embedded at campus activity and the term of 'homesickness' could be worthily labelled.

Other cases could be caused by mutual interaction of academic advising performed between lecturers and students. Actually, in real practice, it was ineffective and insufficient academic communication to cope with students' problems because students only saw their advicers for academic consultation when filling the form of their academic re-enrollment twice for a year. Another indication could be seen from the amount of dropping out students that augmented gradually for each class of English language major in each semester. Eventually, 
from all the problems above, the academic satisfaction could be a difficult thing achieved by the students and these should become the main issues to be seriously paid attention by all members of the college. Based on the backgorund above, the writer focuses the discussion on "the Impacts of Academic Services and Campus Atmosphere to Students' Satisfaction and Retention at the State College for Islamic Studies Students of English Education Major of Syaikh Abdurrahman Siddik Bangka Belitung.

\section{FINDINGS AND DISCUSSION}

This section discusses the survey results, interview and observation analysis the impacts of academic services and campus atmosphere to students' satisfaction and retention. Broadly, student satisfaction has been defined in many ways. In related word, 'self-satisfaction' or 'selfpride' can mean 'complacency'. In this respect, as stated by John (2002):

"Complacency is a feeling of self-satisfaction. Content with the status quo, organizations and individuals that are complacent do not look for new opportunities or hazards on the horizon, instead they are almost always internally focused. They rarely initiate or lead, working at a constant speed even when circumstances call for fast action. We have all seen it, yet we underestimate its prevalence and its power. Highly destructive complacency is, in fact, all around us."

When students have a feeling of self-satisfaction, they would not search for other complacency because they were always internally focused. This was due to "complacency almost always comes from fame, and lives long after that success has vanished. In contradictory, a sluggishness or arrogance might be clearly apparent to an outsider, complacent insiders don't have that perspective" (John, 2002). Once they dissatisfaied with the services given by their campus, some problems might reveal which affect their academic life.

Concerning the administrative and informational service, plenty of students (67\%) complained to administrative system that was unpleasently and dissatisfactorily given by the staffs. Although some of them admitted that a few staffs were individually cooperative and had good manners, but many of them seemed to be quite unfriendly and unapproacable. Besides, the informational system in touching on academic schedules were late to be issued to the academic community. Consequently, frequently felt disappointed when knowing that they were treated unpleasently.

Student did not feel academically when staying on surrounding the campus (50\%) because this campus location closes to the jungle. In consequence, they got difficulty to access the transportation if they did not have private vehicles because it is far away from their dorms, even it is also far away from the township.

In line with the findings above, Cranny et al. (1992), Decenzo \& Robbins (2010) in Tessema, et al, (2012) stated that interest in factors affecting satisfaction have increased in academic settings. This was mainly due to the fact that satisfaction affected both individual and organizational performance. According to Elliott and Healy (2001) in Tessema, et al, (2012) that student satisfaction was a short-term attitude based on an evaluation of their experience with the education service supplied. As a dependent variable, satisfaction was explained by a number of academic-related factors such as advising, quality of instruction, individual relationship, and class size (Corts et al., 2000; Elliott, 2003 and Peterson, et al., 2001 in Tessema et al, 2012).

The courses distribution of the curriculum offered in each semester, plenty of them (49\%) were somewhat dissatisfied due to the combination of both English skill-based curriculum and religion-based curriculum that made them could not focus on the main goal of their study. Since they did not have adequate basic knowledge of the religious courses in relation to the requirement of the curriculum from the previous school. In consequence, they got difficulty to 
adjust their academic ability for both of curriculum.

"We think we could get the balance knowledge of the curriculum combination of both English skill contents and religious contents. Although the religious courses offered by the college only on the introduction as the basis for our thought development, but we could know a little bit about it. However, we should understand that our main focus on this curriculum is to get more knowledge to the acquisition of English skills that would support our practical skills after we finish our study."

Regarding the statement above, college should reassemble the curriculum in order to come to shared-demands between the institution necessities and students' needs. These split requirements should fulfill to the current educational epoch and global educational development wherein the cultural, political, economy, and personal characteristics of students as the basic element of the curriculum development. As stated by Linse, in Hudelson (1993) in Richard (2001) that it is the school responsibility to take into account the cultural, political, economy, and personal characteristics of students as the curriculum which is developed in order to plan activities and objectives that are realistics and purposeful. It is not school reposnibility to act on political matters, but it is school responsibility to provide equal access to school opportunities and to validate the experiences of all students, regardless of their political and/or cultural background." Therefore, the college should be responsible to plan the curriculum that meet the requirements to the development of cultural, political, economy, and personal characteristics of students. Besides, the college also has responsibility to provide equal access to college opportunities and to validate all students' experiences.

When they were asked about their satisfaction with 'academic guidance \& counseling,' $50 \%$ students discouraged and did not enjoy their academic advice. As they expressed:

"We frequently did not feel enjoy with the process of academic guidance and counseling with our advisers because did not motivate and encourage us how to solve our academic problems."

Additionally, 50\% students stated that they did not accept the appropriate academic guidance and counseling because the academic advisers did not appreciate them well. Besides, they were likely to be very busy with some additional activities. In addition, they seldom got boost of motivation given by their advisers. As they said:

"We seldom felt happy when seeing our academic advisers because they seemed unapproachable and uncomfortable and they often showed negative attitudes and behaviours when dealing with to us. Besides, some of them did not motivate us but discourage to what we had done. In short, we think that they were not welcome people to discussions and different in opinions."

Academic guidance progression was one of the factors through which a student could improve his or her study attitudes and study habits and was directly proportional to academic achievements. The students who were properly guided by their lecturers positively affects their performance (Hussain, 2006) in Mushtaq \& Khan (2012).” Regarding this, academic advising, it refers to "the extent to which students were satisfied with guidance process, including accessibility of faculty and the quality of the interaction with their advisors. And then, close relationships with faculty, especially as part of the advising process, were instrumental in students feeling connected to their institution (Corts et al., 2000; Russell \& Lehman, 2008 and Gordon, 2005 in Tessema (2012).”

Corncerning 'the classroom context', many students (65\%) whined that they were mentally impressed by the threatening classroom environment. It was undeniable that the students did not enjoy the class session because there were some certain lecturers behaved unpleasently. They 
argued that those teachers were too rigor. Whereas, service-learning works to promote academic, social, and civic development in our youth (Evers, 2010). Besides, based on the institutional approach, academic service-learning should give students opportunities to increase their knowledge and skills while making positive contributions to academic development. Because young people make a difference by meeting real community needs, service-learning gives them more motivation to learn, a greater understanding of how to put their learning to good use, and a sense of democracy in action.

To solve the problem above, Finch (2001) suggested the debilitative anxiety-the promotion of a low-stress language learning environment that should be an essential priority for the lecturers. Self-examination on the part of the teacher, involving encouraging realistic expectations about accuracy and errors, offering training in affective strategies, is directed to help students manage anxiety and improve performance, reassuring them that they are not alone in their affective reactions and that these feelings are normal, making or choosing appropriate learning materials, and showing that the lecturers understand the tensions caused by language learning pressure. And then, self- and peer-assessment involving partner and small-group work, interviews, problem-solving, and practice of test-tasks are also an effective and relative painless means of involving students in the learning and assessment process, and can reduce anxietyraising competitiveness and apprehension."

In line with the solution above, Evers, et. al, (2010) also suggested "to increase students' academic skills in core content areas. They are provided service-learning experiences in the classroom to develop relevant and practical skills like critical thinking, problem solving, and communication skills. They practice teamwork and action planning, connect meaningfully to adults in their communities, and they explore creativity while learning academic concepts through integrated projects. Besides, helping them graduate with the knowledge and skills needed to be successful in the workforce or further education. True academic service-learning requires students to take an active role in both the learning and assessment process. Because youth take greater ownership of their learning, service-learning results in higher academic achievement. An added benefit to what transpires in the classroom, academic service-learning provides them opportunities to practice citizenship skills, increasing the likelihood that they will stay actively engaged in their communities throughout their lifetime.

Regarding library learning access, they were also dissatisfied, because they frequently got difficulties in obtaining what they wanted that deal with their learning access.

"It's unbelievable that we often got uncomfortable treatment when attempting to check in the library to access the learning resources of searching some books. The librarian frequently behaved unprofessionally to us. It seemed that they did not give us a large opportunities. Whereas, we needed their help to support our academic works. But, they seemed not helpful and care."

In accordance with 'learning resources,' most of students stated that they were dissatisfied with it because in general they got difficulty in the term of learning sources, as complained by them:

"As we know that the access to obtain learning sources were quite difficult. Almost all learning resources had to be individually efforted by ourselves. Although some of the resources were individually prepared by the lecturers and rarely provided by the college itself, but we can say that everything was almost limited. In consequence, we got difficulty in enhancing our skills in language proficiency."

In addition, the college were not able to prepare adequate learning sources. This unsatisfactory learning sources such as reference books, ensiclopedias, dictionaries in library made them difficulty in fulfilling and accomplishing their tasks. Besides, some librarians 
seemed to be unfriendly when welcoming students to check in or when serving them to search some learning resources. In short, they did not feel quite inhabit when intending to check in or even when settling on the library.

Dealing with 'campus extra-activities and programs,' a great deal of them $(70 \%)$ were somewhat dissatisfied with them. As stated by them:

"Actually, this college has done some extra-activities prepared for students but those activities frequently did not match with our needs due to different individual talents and interests. In addition, sport and facilities were quite restricted to be prepared by the college."

Some students were dissatisfied (45\%) because the campus events were rarely done. Whereas they really needed some additional activities and events organized by the college. As stated by some of them:

"We were definitely keen on involving in much more extra-activities such as workshops, seminars, contests, etc. because from which we could enhance our knowledge and improve our skills to support our language proficiency."

As of the statement above, it semeed that the students were eager to be involved in a variety of campus activities. However, it would be well-recommended if this college could organize much more activities that could enrich their knowledge and improve their skills.

Concerning 'the campus facilities \& infrastructure,' most of them $(80 \%)$ complained to the damaging certain classrooms and toilets, internet service that habitually disconnected, unhealthy canteens, unsufficient parking area, and unsatisfactory sport facilities, and unavailability of the proper place for prayer.

From all of the findings above, it is important to note that there are some other service types to support students' learning satisfaction that have to be included here, such as 'the service of health insurance and transportation.'

To achieve the necessary standards of 'health and safety service,' a positive commitment is required from all members of this college. It is the responsibility, under the health and safety at college legislation, of every staff and student or other person working or learning on college premises to ensure that they do not, except where it is unavoidable, create hazards for themselves or others. All reasonable steps should be taken to eliminate or minimise such hazards and any item causing a hazard or obstruction that should be overcome by this college. Therefore, due to this college have not yet implement 'individual health insurance' for each academic members, so all of them have to make a commitment of creating health and safe campus atmosphere. Additionally, another service that probably important to provide is the transportation service. However, this is an essential thing to take into account in order to assist the college in achieving its outstanding missions effectively and assisting students for the easiness in accessing their campus. In short, 'the service of health insurance and transportation' can be one of the college agenda to prepare.

In connection with all the problems and discussions above, "it is acknowledged that the majority perspective of satisfaction was directed between the customer and service provider relationships. In this case, point of view derived from a marketing perspective. The fundamental idea of a marketing perspective is that there was an exchange of money for goods, services or information that was satisfying to both the purchaser and the provider (Kotler, 1967) in Greiner (2002)." Additionally, Kotler and Fox (1985), Ryans and Shanklin (1986), and Shoemaker (1997) in Greiner (2002) extended "the notion of marketing from a description of a private sector business activity, to a higher education activity. In higher education, student money, time, and energy were exchanged for information and education provided by faculty." And then, yet in Greiner (2002), "a satisfying exchange relationship between the consumer and the provider was a must, from the consumer perspective, provide customer satisfaction." Therefore, 
as stated by Boulding, Kalra, Staelin and Zeithaml (1993), and Parasuraman, Zeithaml, and Berry (1985) in Greiner (2002) described "customer satisfaction as the difference between observed and expected quality. The difference was described as the 'disconfirmation' or 'quality gap.' A positive gap suggested the product exceeds expectations while a negative gap suggests the product quality did not meet expectations.

From all of the statements and findings above, if the 'negative gaps' dominantly took more places on the academic services and academic atmosphere, students' academic dissatisfaction could prominently appear. And students' academic retention is the final positif impact of students' satisfaction and campus atmosphere. But, in contradictory, the failure of this campus in maintaining students' retention is the main problem. Particularly the students of English education major of SAS Bangka Belitung have gradually decreased and this phenomenon has happened since two years ago.

Due to the constricted academic service quality and uncomfortable campus atmosphere, a great deal of students was academically dissatisfied." In addition, in line with the findings of the present study, the previous related studies conducted by Cameron and Ettington (1988), Hartnett and Centra (1977), Archambault (2008), and Lotkowsky et, al. (2004) showed that "the college service performance could also influenced students' satisfaction and retention. In addition, the non-academic factors of academic-related skills, academic self-confidence, academic goals, institutional commitment, social support, certain contextual influences (institutional selectivity and financial support), and social involvement all had a positive relationship to the students' academic retention. Furthermore, the academic service and instructional quality (i.e., enthusiasm, organization, and rapport) have a high correlation with learning satisfaction. Eventually, regarding the non-threatening learning environment, in a classroom context of learning, debilitative anxiety-the promotion of a low-stress language learning environment that should be an important priority-not only for the teacher but also for all academic planners and staffs. In this case, self-examination on the part of the teacher, involving encouraging realistic expectations about accuracy and errors, offering training in affective strategies, to help students manage anxiety and improve performance, reassuring them that they were not alone in their affective reactions and that these feelings were normal, making or choosing appropriate learning materials, and showing that the teacher understood the tensions caused by learning. Self- and peer-assessment involving partner and small-group work, interviews, problem-solving, and practice of test-tasks were also an effective and relative painless means of involving learners in the learning and assessment process and could reduce anxiety-raising competitiveness and apprehension in learning."

\section{CONCLUSION AND SUGGESTION}

This college was constricted by some restrictions, but students tolerated with all of those embiances. Campus atmopshere was not their foremost concern to achieve their contentments in learning but academic service became their prominent burdens. Besides, what they needed were both complete learning mediums and facilities to prop up their academic achievements and contentments. Once they dissatisfaied with the services given by their campus, some problems might reveal which affect their academic life.

Students' dissatisfaction with academic service quality should be a central highlight of this college attention. Academic service quality must be refixed on. Besides, campus atmosphere must be dynamically reconditioned to create a better campus life. All academic members should be encouraged to be actively envolved in college development.

All suggestions above were devoted to protect this college from experiencing the worse impacts for students that might appear in the future. Some impacts that the writer found in this study, students frequently got late to get in the classroom sessions due to campus location is far away from the township and their dorms. Besides, because there was no a regular public 
transportation access, they often got absent. They did not feel quite inhabit when searching in or even when settling on the library. They had inqualified academic capability because of limited learning sources. Since they did not have adequate basic knowledge of the religious courses prior to the college curriculum. In consequence, they got difficulty to adjust their academic ability for the combination of both English skill-based and religion-based curriculum that made them could not focus on the main goal of their study. Additionally, they felt incomfortable to some leacturers, consequently the retired from enrolling to the next semester, they dropped out.

It would be well-adviced to all of the academic members in order to improve their academic services to their students; particularly to the administration staffs-improving the academic service quality could be the central priority, the librarians should be professional in facilitating students' needs for searching any learning resources and be cooperative with students in library access, the lecturers can be more flexible and professional, the academic advisers should be more friendly and comfortable. Finally, for the part of college persons in charge in order to manage this campus appropriately to achieve its missions and goals to the right straight in producing the skillful students that meet the requirements of global era, because service quality and satisfaction in academic contexts are important concepts as a means of consumer evaluations to create a competitive advantages and loyalti in sustaining students' retention.

Eventually, the researcher was fully aware that this study might be far from satisfying anybody for those focusing on such this research and the researcher entirely admits for the constraints. Thus, for other researchers who are interested in conducting such this research, it is fully expected in order to conduct for more specific related issue in deep inquiries because not all findings were included in this study. Besides, some useful suggestions are fully demanded for the improvement of this study.

\section{REFERENCE}

Aldosary, AS., (1999). Students' Academic Satisfaction: The Case of CED at KFUPM. The Journal of JKAU: Eng. Sci., vol. 11 no. 1, pp. 99-107 (1419 A.H. / 1999 A.D.) King Fahd University of Petroleum and Minerals. Dhahran. Saudi Arabia

Antonio, A.L. et. Al., (2005). Making Diversity Work on Campus; Preparing Students and Campuses for an Era of Greaters Expectations. The Association American Colleges and Universities. http://siher.stanford.edu/makingdiversitywork.pdf

Archambault, L.Z., (2008). Measuring Service Performance, Student Satisfaction and Its Impact on Student Retention in Private Post-Secondary Institutions. The EDU-COM 2008 International Conference. Sustainability in Higher Education: Directions for Change, Edith Cowan University, Perth Western Australia, 19-21 November 2008.

http://ro.ecu.edu.au/ceducom

Bacsich, et. al, (2007). Reviewing Virtual Campus Phenomeon. The Rise of a Large-Scale eLearning Initiative worldwide. EuroPACE Publisher: European Commission, Paris

Brown, H.D, (1994). Teaching by Principles; An Interactive Approach to Language Pedagogy. United State of America: Prentice Hall, Inch. Englewood Cliffs, New Jersey

Brown, H.D, (1994). Principles of Language Learning and Teaching. Prentice Hall Inc., United State of America. 
Bastiaens, T. et. al., (2007). Reviewing the Virtual Campus Phenomenon. EuroPACE ivzw. Kapeldreef 62, 3001 Heverlee

Delaney, J. et. al., (2010). Students' Perceptions of Effective Teaching in Higher Education. Board of Regents of the University of Wisconsin System. http://www.uwex.edu/disted/conferenc

Evers, et. al., (2010). A Guide to Implementing Quality Academic Service-Learning. Wisconsin Department of Public Instruction. http://dpi.wi.gov/fscp/slhmpage.html

Finch, A, (2001). The Non-threatening Learning Environment. Published by Kyungpook National University Publication

Greiner, Keith \& Westbrook, Thomas S.K, (2002). Academic Service Quality and Instructional Quality. The Journal of the First-Year Experience and Students in Transition. Iowa College \& Drake University. Fall 2002, Volume 14, Number 2, pages 7 - 30

Grace University, (2012). The College Students Handbook. School Datebooks, Inc. All rights reserved. School Datebooks, Inc. 2880 U.S, Hwy 231, S. Suite 200. Lafayette, IN 47909. South Ninth Street Omaha, NE 68108-3629. http://www.schooldatebooks.com

Hadley, O. A, (2001). Teaching Language in Context. Boston, United State of America: Heinle $\&$ Heinle, a Division of Thomson Learning, Inch

Harry, K. Wong, (1999). There Is Only One Way To Improve Student Achievement. http://www.newteacher.com

Jin, C, (2013). A Study of University Culture Construction Based on Learning Organization Theory. http://www.ipedr.com

Kotter, John, (2012). Complacency. http://www. Kotter International.com/ourprinciples/urgency/complacency

Korobova, Nadia, (2012). A Comparative Study of Student Engagement, Satisfaction and Academic Success among International and American Students. Digital Repository @ Iowa State University. http://lib.dr.iastate.edu/etd

Loveys, Jane, et. Al., (2013). Campus Life of Bath University 2012/2013. www. Bath.ac.uk/accommodation.com

Lee, D. (2002). Learning and Teaching Briefing Papers Series; Oxford Centre for Staff and Learning Development. Oxford Brookes Universities. http://www.brookes.ac.uk

McNeel, Jon, \& Amstutz, Marilyn, (2013). Living in Community Of Grace University. www.schooldatebooks.com

Miller, K.F., (2008). Services Quality in Academic Libraries; An Analysis of LibQual+TM Scores and Institutional Characteristics. A Dissertation in the University of Central Florida. www.libqual.org 
Nolte, H. (2011). Blinn College Administration. www.sacscoc.org.

Noel \& Levitz, (2010). Student Satisfaction Survey of Student Satisfaction with Student Services, Academic Services and Campus Climate. Finance and Planning Office of Institutional Research. Community College of Philadelpia. http://www.ccp.edu/pdf

Ostrom, A. \& Iacobucci, D., (2001). Distinguishing Service Quality and Costumer Satisfaction; The Voice of the Costumer. Published by Lawrence Erlbaum Associates Inc. Northwestern University and London Business School.

Richard, J. (2001). Curriculum Development in Language Teaching. Cambridge University Press. United Kingdom

Tessema, MT., Ready, K. and William Yu, W-C, (2012). Factors Affecting College Students' Satisfaction with Major Curriculum: Evidence from Nine Years of Data. The International Journal of Humanities and Social Science Vol. 2 No. 2_Special Issue-January 2012

The Students Behavior Consultation Teams, (2011). Recognizing and Helping Students in Distress; A Guide for Faculty and Staff. University of Delaware. www.udel.edu

Tinto, V. (1993). Leaving College: Rethinking the Causes and Cures of Student Attrition (2nd Ed.). University of Chicago. United State of America

Westbrook, T. S., (2005). Students Perceptions of Academic Services and Instructional Quality over a Four-Year Academic Experiences. Journal of Research In Education. Fall 2005. Vol. 15.

http://www.eeraonline.org/journal.pdf 